УДК 929 Караџић, Вук Стефановић 929 Вилсон, Данкан https://doi.org/10.18485/msc50_vuk_trsic.2021.ch25

\author{
Елизабета Вилсон
}

\title{
ВУК И ЊЕГОВ ЕНГЛЕСКИ БИОГРАФ
}

Велика ми је част што сам позвана да учествујем у овом историјском тренутку и да будем у граду и простору тако живо повезаном са Вуком Караџићем. Вук је послао свог сина мезимца Саву у вашу чувену гимназију; у близини је и дивна Фрушка Гора, где је Вук обичавао да борави у манастиру Шишатовцу са својим пријатељем и раним учитељем Лукијаном Мушицким, недалеко су и Карловци где је и сам Вук једно кратко време похађао школу којој је на челу стајао Митрополит Стратимировић, дугогодишњи, животни противник његовог правописа, његовог Рјечника, његовог превода Новог завјета. На другој обали реке је Петроварадинска тврђава, некадашње седиште аустријског команданта који је одбио Вукову молбу да се врати у Карловце 1831. У Карловцима је Вук срео свог најбољег певача Тешана Подруговића, у Шишатовцу слепца Филипа Фишњића. Колико је пута само Вук морао пролазити кроз Нови Сад или остајати у њему у време својих многобројнх путовања од Београда до Беча и назад. Штавише 1863. је забележено:

„... Цео се Нови Сад узбудио а тако и Сремски Карловци и њихова околина. Стигао глас да долази Вук Караџић!... Људи су се... при сусретима, на јавним местима, у кафанама и крчмама, на улицама, свађали и тукли, као крвни непријатељи... Једном делу... славом овенчани народни вођ, као оно библијски патријарх... другом делу „Хроми даба”, „шантави ђаво”, бечки и ватикански агент..., Вук је био средиште контроверзе све до своје смрти.

Ја се веома устручавам да говорим пред толиким бројем научника светског гласа. Нисам ни научник, ни историчар као што је био мој муж Данкан. Али како, нажалост, он не може данас бити овде, веома сам срећна да нешто мало могу да проговорим о њему, о његовом одушевљењу за Вука, о томе како се одлучио да напише своју књигу „The Life and Times of Vuk Stefanović Karadžić”, Oxford University Press, 1970. 
Једном ми је било постављено питање како је Данкан могао наћи времена да напише тако обимно научно дело за време док је био британски амбасадор у Београду. Можда је питање садржавало и прикривен смисао, подразумевање да ако неко добро ради свој посао не би смео да има времена за тако нешто. Одговора на то питање има, међутим, много.

Данкан је био веома брз и концентрисан радник, већ је добро владао српско-хрватским, тако да за њега није било проблема у коришћењу оригиналних извора, био је човек далекосежног ума и широког образовања, начитан из области европске историје 18. и 19. века, био је угледан класичан филолог, потпуно у току хомерских студија, заинтересован за теорије о пореклу епске поезије. Али изнад свега тога, за Данкана је писање књиге био рад из љубави, не задатак; он није жалио да јој посвети све своје слободно време, уживао је у томе и ми са њим. Посветио је књигу својој породици, а то је за нас веома драгоцен поклон.

Желела бих да истакнем још нешто. Наша влада је увек имала врло широке погледе на дужности својих дипломата у иностранству, она нас је охрабривала да се што дубље упознамо са земљом у коју нас шаље; одобравала је путовања, омогућавала их, давала нам времена; схватала да ћемо управо следећи своја сопствена интересовања и хобије склопити многа пријатељства и тако дубље разумети земље у којима службујемо. Не очекује се од свих дипломата да се понашају према обрасцу, пошто смо посматрани као индивидуалности, од нас се тражи и да дамо свој сопствени, лични допринос. Чини ми се да је наша влада поносна што је један од наших амбасадора написао књигу толико цењену у Југославији да се и преводи на српско-хрватски. Нашој влади смо за такав став захвални.

А сада како је уопште Данкан дошао на помисао да пише о Вуку? И на ово питање има више одговора. Пре свега, 1964. година када је Данкан именован за британског амбасадора у Југославији била је погодна - поклапала се са прославом стогодишњице Вукове смрти. И ја бих пре свега нарочито хтела да искажем своју захвалност покојном др Ђури Гавели и др Јелени Шаулић из одличног Вуковог и Доситејевог музеја у Београду, који су први указали Данкану на Вуков фасцинирајући живот и његова достигнућа и пружи му непрестану помоћ и стална охрабрења. Радост ми је што је Јелена данас овде и што могу и лично да јој се захвалим.

Постоји, међутим, још једна срећна околност, коју чак не могу ни довољно да нагласим, а то је да смо ми са службом били у Југославији и раније, од 1951-1953. Те две године биле су несвесна припрема за Данканову књигу - он тада не само да је научио српско-хрватски, него је стекао нешто што бисмо можда најбоље могли назвати „осећај за Југославију”. 
Обоје смо се тада очарали Југославијом, били опчињени њеним људима. Били смо млади и пуни енергије и ништа нам није било драже него да за викенде, па било да су они били дуги или кратки, кренемо за манастире и у планине са врећама за спавање и са једним или више пријатеља Југословена. Овде бих желела посебно да се захвалим једном од њих професору Радету Стојановићу, нашем српском учитељу, који је обично био са нама и упознавао нас са многобројним пријатељима које никада нећемо заборавити.

А случајно се и догодило да су сва наша путовања водила у како би Вук рекао: „Језгро Србскога рода, и најчистијега језика” које се „находи... између реке Дрине и Мораве”, део Србије јужно од Саве. Овај наш избор није био хотимичан (мада смо заиста волели земљу), већ нас је определила близина Београду. У свом предговору Пјеснарици из 1814. Вук је написао: „...они су Србљи, као робови будући, више до данас задржали свога Национализмуса, него ови амо у просвешћеном и слободном Царству", али је и осећао да се Срби досељеници у Аустрију, ипак нису одродили од своје родне груде.

Били су то славни дани за нас. Истина, путеви су били ужасни, и није било кампинга, али управо зато смо могли да се сместимо поред пута, слободни као птице, да лежимо на травњацима златног Златибора, испод звезда, без живе душе на помолу. Јутром би нам понека сељанка донела млека или јаја, а деца док бисмо возили понудила у корпици од лишћа купине, али знак „Забрањено паркирање” никада нисмо видели. Једног раног априла камповали смо високо на Гламочу (овај пут у Босни), скоро на ивици снега. Деца су нам била мала, те смо имали шаторе, а били смо и ближе селу, да би пријатељ који је био са нама, инвалид, могао да одседне у крчми. Ујутро је цело село дошло да нас гледа како доручкујемо, а онда смо угледали милицију како се приближава и помислили да ће нам наредити да се склонимо одатле. А они су дошли да подсете децу да је време за школу!

Нису мени остали у сећању само дивни предели, већ још више људи које смо сретали. И кад год прочитам Данканову књигу о Вуку сећам се тих дивних путовања, снажно осећајући ваш историјски континуитет. И чини ми се и сада да ти стамени људи нису били само Вукови потомци, већ да су били од исте грађе саздани као и Вукови савременици.

Сећам се једног раног марта 1952. године када смо провели недељу дана с нашим „српским учитељем” у планинарском дому на Тари, били смо високо под снежном границом. Раде је љубазно инсистирао на томе да треба да говоримо и слушамо само српско-хрватски, што је било веома напорно за нас, али још више за њега. И данас видим нашег домаћи- 
на, постаријег сељака који као да је са својим засуканим брковима сишао са Вукове фотографије. Сећам се и како је једном ударио песницом о сто говорећи: „Ја сам свој господар!” Сећам се и његове жене која је правила најтањи, величанствен стољњак од теста за питу, дуг до пода, а под без и једне мрље, као и цела кућа, пречист. А како је тек пита била укусна, после нашег пентрања по планини, по снегу, и то послужена уз „шумадијски” чај. То је та снажна независност и упорност у којој је Вук подизан и њему слични.

Другом приликом, сећам се видела сам једног веома стаситог наочитог старијег човека у чакширама и фесу. Газио је по тада блатњавим улицама Београда. Посматрала сам га онако с његовим орловским носем и природним плавим очима загледаног у даљину, и помислила: „Какав ли је био живот овог човека, кад у својим шездесетим корача као краљ?” Његов став је очигледно показивао човека чија је храброст и истрајност у ватри опробана и који није чекао да изврши своју дужност.

Сећам се да смо једног јула били гости у летњиковцу једног сјајног лекара и његове жене из Врњачке Бање, који су имали на Гочу. Једног дана смо пешачили дванаест часова да бисмо стигли до Жељина и још осам или више миља да се попнемо на његов врх од 2000 м. Једно сељаче нам је било водич. Сећам се његовог лаког дугог корака, за који сам изјутра у 3.30 , глупо помислила да ћу га лако следити, корака који се није мењао цео дан, ни по узбрдици, ни по низбрдици, ни усред подневне жеге. Када смо се увече растали, пружио нам је руку и рекао: „Сада смо браћа!" Осетили смо се веома поносним.

Једном смо опет спавали напољу у Ибарској долини, уочи пењања на Копаоник. Био је октобар и рано се смркавало. Једна стара сељанка видела је са свог прозора дим наше ватре, устала је из кревета и донела нам огроман свежањ прућа из свог дворишта, да би нам у току ноћи било топло. О како смо је благосиљали у рану зору!

Другом приликом на путу за Дурмитор, наша кола су почела да „кашљу” на једној од стрмих кривина после Новог Пазара, те смо их довезли до „гараже” у најближем селу. У гаражи, да је тако назовемо, видели смо углавном јармове, плугове и опрему, и само један расклиматани аутобус. Али срце нам је од радости заиграло кад смо га угледали; јер ако су ови људи могли такав аутобус довести преко планине и таквим путевима, онда сигурно могу оправити и наша кола. И заиста се нисмо преварили, додуше нигде није било складишта резервних делова. Но узбрдо се појавио возач аутобуса, завукао руку у свој џеп и оданде извукао свећицу, и решио проблем.

Још само једна прича. Када је Данкан поново дошао у Београд као амбасадор, код нас се запослио момак по имену Мићо, који је такође био 
из Тршића (Тррршића, како га је по Вуку, изговарао Милош). Више пута смо посетили његову кућу, и како смо морали пешачити узбрдо једно две-три миље од колског пута до његовог села, он би нам показивао клисуру у којој се његова породица крила када су јој Немци спалили кућу. Тада би се Данкан сетио да је Вуков отац сам десет пута градио своју кућу у Тршићу у јесен, да би је Турци опет у пролеће спалили!

Били смо и на Мићиној свадби. Он и његова невеста познавали су се још од детињства, или како би га Вук описао као „најсрећније состојаније смерти” када је „овце и козе чувајући живио”.

Времена су се невероватно мало била променила у Србији.

Нећу да се извиним за ова лична сећања. Причам их јер мислим да су ова згуснута искуства која су испунила Данкана, управо му и омогућила да разуме Србију, не само Србију данашњице, него исто тако Вукову Србију. Тако је могао јасно сагледати како су Срби који су збацили Турке, могли да постану партизани 1941, и како су са другим народима у Југославији, под вођством великог лидера Тита извојевали једну од најјуначкијих битака нашег времена - свих времена. И тако, када је Данкан почео да пише о Вуку, он га није видео само у међународном контексту него и у окружењу његове родне земље - Србије на коју је био толико поносан и за коју је тако много урадио.

Али на крају крајева, мора се рећи да је пре свега сам Вук фасцинирао Данкана. Критичари су писали „о симпатијама и разумевању које је Данкан показао према Вуку”, и о његовој објективности.

Мислим да је најбоље, илустрације ради, да вам укажем на неке закључке из Данкановог последњег поглавља (које вам топло препоручујем да прочитете) и да цитирам неке одломке из оквира његових општих оцена о Вуковом карактеру и његовим достигнућима.

Данкан, на пример, пише о значајном пријатељству које је никло између Вука и Словенца католика, Јернеја Копитара, генералног цензора за словенске језике у Бечу, и првог истакнутог Аустро-Словена, који је желео да заклони Словене централне и источне Европе од руског утицаја и да претвори Беч у главни центар словенске културе. Вук је очигледно за Копитара значио савезника, али Данкан запажа и нешто друго: „Копитара је по свој прилици привукла пре свега Вукова јасна сељачка мисао, његова поузданост у закључивању, и његово родољубље”. На другом месту Данкан додаје: „Вероватно да је Вуку сељачко васпитање, недостатак формалне образованости, и предрасуда и помогло да непосредно сагледа ствари и да их назове најједноставнијим именом".

Иако је сматрао да је „просвешћеније” Србе у Аустрији начинило понекад мање Србима, сам је „имао страст за знањем, и гајио је веру у 
добробит учености, карактеристичну за оне који морају да се боре да би стекли образовање”. Вук је веровао у непобедивост здравог разума, али је често у полемикама његово понашање било арогантно и често није прихватао аргументе. У суштини је био дирљиво несвестан колико борби за његову ствар мало служи да буде у праву „у погрешно време и на погрешном месту”. Па ипак је на крају живота могао да каже да је његова тактика постигла свој циљ.

Данкан је такође видео раскорак између Вуковог страсног подређивања истини, и понекад бедним околностима у којима је проводио живот, када је био принуђен не само да моли, већ и да ласка безвредним властодршцима, што се посебно види из његовог дела о Животу Милоша Обреновића из 1827.

Али уз овај значајни изузетак, Данкан истиче да су „Вукове историјске белешке изванредне управо због његове савршене тачности у детаљу. Пажљивим одбиром конкретних и детаљних тренутака људских слабости као и хероизма хајдука и вођа српских устанка, Вук читаоцу пружа општи увид о томе из чега се рат и јуначка акција састоји, што све постаје више дирљиво и дубље трагично када се сагледа на позадини нормалних људских осећања."

Када се погледа цео Вуков живот, тешко је сагледати „сву разноврсност спољних препрека на његовом путу. Поред тога што се морао борити са моћним противницима, морао је и да бије битку највећим делом свога живота, против беде и породичних невоља, и смрти своје деце (од 13 само је четворо преживело рано детињство), и сопствене болести. Да би остварио свој пуни програм у оваквим условима била му је потребна изузетна храброст и упорност".

Данкан је од свих Вукових дела највише ценио његова достигнућа у језику. Начинио је Граматику и Рјечник српског језика, увео нову азбуку и нов ортографски систем, а прикупљајући народне песме и преводећи Нови завјет, увео је у литературу народни језик, и тако је начинио широко приступачном. Данас је тешко и замислити, после потпуне његове победе на лингвистичком пољу, каква је то борба била. И ауторитет и сила били су на страни његових противника. Била му је потребна изузетна енергија и марљивост да би придобио публику за своје нове погледе.

Вукова непопустљива одлучност у правопису, његово страсно инсистирање на једном језику за све Јужне Словене, сигурно да је више од свега учинило могућним стварање данашње Југославије.

* Рад је претходно објављен у зборнику Научни састанак слависта у Вукове дане, 17/4, 337-342. 